\title{
Trichoderma and Bradyrhizobium japonicum bioformulates on soy initial growth
}

\author{
Luana da Silva Cadore '; Rosana Taschetto Vey " \\ Jean Carlos Frezingheli de Fresinghelli "II ; Lucas Dotto IV \\ Francielly Baroni Mendes v ; Antonio Carlos Ferreira da Silva vı
}

\begin{abstract}
Bioproducts can act on plant development in a positive, negative or neutral manner, as well as whether there is interaction of these products when used with other biological bioproducts, often used in soybeans such as Bradyrhizobium japonicum. The objective of this work was to evaluate the action of two trichoderma-based and two Bradyrhizobium japonicum-based bioformulates, combined or not, on variables in the early development of soybean plants, free of phytopathogens. The soybean cultivar Nidera 5909 was used and the treatments consisted of four commercial bioformulates, based on Trichoderma harzianum, Trichoderma sp. and two based on Bradyrhizobium japonicum, being tested in association and /or isolated for soybean seed inoculation. For the seedling emergence variable, there was no difference between the treatments tested. By analyzing the leaf variables such as leaf area, shoot length, fresh and dry shoot, the use of liquid B. japonicum results in higher averages compared to the other bioformulates. When evaluating root length, root surface area, root volume and root dry matter the use of bioformulated with Trichoderma sp. as active ingredient presented the highest averages. It was concluded that the use of Trichoderma sp. and Bradyrhizobium japonicum liquid in their isolated form, provide better initial development for soybean crop.
\end{abstract}

Keywords: Glycine max; Microorganisms; Seed treatment

\footnotetext{
'Universidade Federal de Santa Maria, Santa Maria, Brazi. Iuanascadore@yahoo.com.br

"Universidade Federal de Santa Maria, Santa Maria, Brazi. rosanatv2103@yahoo.com.br

I"' Universidade Federal do Pampa, Itaqui, Brazil. fresinghelli@yahoo.com.br

Iv Universidade Tecnológica Federal do Paraná, Pato Branco, Brazil.: lucas-dotto@hotmail.com

$\checkmark$ Universidade Federal de Santa Maria, Santa Maria, Brazi. francielly_baroni@hotmail.com

vi Universidade Federal de Santa Maria, Santa Maria, Brazi.: acfsilva2@uol.com.br
} 


\section{INTRODUCTION}

Soybean crop (Glycine max L.) is one of the main grain crops in terms of consumption and production. Approximately $90 \%$ of soybean consumption is used for processing, of which $80 \%$ is used as raw material for feed production and $20 \%$ reserved for oil production (ESPÍNDOLA \& CUNHA, 2015). According to data from CONAB (2018), in the 2017/18 harvest Brazil obtained a production of approximately 118 million tons of grain.

It is known that the management adopted before the cultivation is primordial to the good development of the crop. It can be mentioned the treatment of seeds as an alternative that aims to protect them from attacks of phytopathogens present in the soil and those linked to seeds (MATHIAS et al., 2017). Currently, the use of microorganisms in seed treatment has been studied in several crops such as beans, corn and soybean (CHAGAS et al., 2017). The use of biological products is an alternative that aims to reduce the environmental risks caused by the excessive use of seeds. also seeking to increase production. Machado et al. (2012) describe the use of trichoderma in plant production due to its wide range of action, since microorganisms act to control important phytopathogens and promote plant growth, having action of hyperparasitism, antibiosis, competition and resistance induction in plants.

Species of the genus Trichoderma are gaining importance as biocontrol agents of diseases and as promoters of plant growth (BENÍTEZ et al., 2004; KUMARIET al., 2016). Trichoderma harzianum is widely studied due to its range of activity, as it produces enzymes and secondary metabolites that can act as antibiotics and in promoting plant growth (FRACETO et al., 2018; LEELAVATHI et al., 2014; DELABONA et al., 2012; VINALE et al., 2009; GOKUL et al., 2000). Bacteria of the genus Bradyrhizobium establish a symbiotic relationship with the plant to perform biological nitrogen fixation on legumes, improving their growth, yield and also the nitrogen content of the plant, and the efficiency of this symbiosis depends on factors such as soil temperature, water and soil, aeration, as well as $\mathrm{pH}$ and salinity (ZIMMER et al., 2016; SILVA et al., 2013). 
Although there are considerable studies on the action of trichoderma as a growth promoter, little is known about its action in the presence of nitrogen-fixing biological products. Granados et al. (2016) reported that when they used Bradyrhizobium sp. along with Trichoderma harzianum, triticale culture presented superior results when compared to the use of chemical fertilizers for some variables such as shoot development and grain yield under water stress conditions.

Biological Nitrogen Fixation (FBN) is a viable alternative to provide nitrogen and plant growth promotion benefits for soybean cultivation, in addition to FBN by Bradyrhizobium bacteria, generating annual savings of approximately $\$ 3$ billion as nitrogen fertilizers are not used. These bacteria act on the root system of soybean plants, being responsible for infecting the roots when the seedlings are developed and later perform the formation of the nodules, which perform the FBN (BARBARO et al., 2009; NETO et al., 2014).

The objective of this study was to evaluate the initial performance of soybean plants through the morphophysiological parameters of shoot and root, using two Trichoderma based bioformulates, combined or not with two based on Bradyrhizobium japonicum.

\section{MATERIAL AND METHODS}

The experiment was carried out in the greenhouse of the Department of Soils and in the Plant-Microorganisms Interaction Laboratory of the Department of Biology, Federal University of Santa Maria, located in Santa Maria-RS.

The soybean cultivar Nidera 5909 was used, because it has the characteristics of precocity and high productivity. The treatments consisted of four commercial products, one based on Trichoderma harzianum (Ecotrich ${ }^{\circledR}$ - 1.1010 UFC.g-1 commercial product, Ballagro Agro Tecnologia LTDA, in the form of wettable powder WP) and the other based of Trichoderma sp. (Trichodel ${ }^{\circledR}$ - 1,109 UFC.mL-1 commercial product, ECCB biological inputs, in liquid form), and two Bradyrhizobium japonicum based products, these being liquid and peaty (Bionutriß Liquid Soybean Inoculant - 
5,109 viable cells .mL-1 of commercial product, Bioagro - Agricultural Industry and Trade LTDA, and Bionutri® Soybean Peat Inoculant - 3,109 viable cells.g-1 of commercial product, Bioagro - Agricultural Industry and Trade LTDA), both acquired through manufacturing companies.

The experiment was carried out in pots containing $0.8 \mathrm{~kg}$ of commercial MECPLANT ${ }^{\circledR}$ substrate, where five soybean seeds were sown per pot. The experimental design was completely randomized with nine treatments (Table 1) and three replications.

Table 1 - Treatments with bioformulates based on Trichoderma harzianum, Trichoderma sp. and Bradyrhizobium japonicum used to conduct the initial growth experiment of soybean plants

\begin{tabular}{|c|c|c|}
\hline Treatments & Commercial Product & *Doses used \\
\hline Control & - & - \\
\hline Trichoderma harzianum & Ecotrich $^{\circledR}$ & $30 \mathrm{~g}$ \\
\hline Trichoderma sp. & Trichodel $^{\circledR}$ & $200 \mathrm{~mL}$ \\
\hline Bradyrhizobium japonicum & Bionutri ${ }^{\circledR}$ liquid & $100 \mathrm{~mL}$ \\
\hline Bradyrhizobium japonicum peat & Bionutri ${ }^{\circledR}$ peat & $100 \mathrm{~g}$ \\
\hline T. harzianum + B. japonicum liquid & Ecotrich $^{\circledR}+$ Bionutri $^{\circledR}$ liquid & $50 \%+50 \%$ \\
\hline Trichoderma sp. + B. japonicum liquid & Trichodel $^{\circledR}+$ Bionutri $^{\circledR}$ liquid & $50 \%+50 \%$ \\
\hline T. harzianum + B. japonicum peat & Ecotrich ${ }^{\circledR}+$ Bionutri $^{\circledR}$ peat & $50 \%+50 \%$ \\
\hline Trichoderma sp. + B. japonicum peat & Trichodel ${ }^{\circledR}+$ Bionutri ${ }^{\circledR}$ peat & $50 \%+50 \%$ \\
\hline
\end{tabular}

*doses used for application in $50 \mathrm{~kg}$ of seeds

The seedling emergence was evaluated by counting of the seedlings emerged every two days from sowing until emergence stabilization, at 10 days after sowing, after thinning, with three plants per repetition. At 20 days after sowing, the plants were removed from the pots, the roots were separated from the soil by washing with water, using $0.5 \mathrm{~mm}$ mesh sieves. Shoot length and shoot fresh weight were evaluated using a precision scale, following the methodology described by BRASIL (2009). After weighing, the leaf area of the plants was determined by separating all the leaves present where they were scanned with the aid of EPSON Expression 11000 Scanner equipped with additional light (TPU) with 600 dpi scanning. 
The images generated by the scanner were analyzed using WinRhizo® Pro 2013 software (Regent Instruments Inc. 2013, Canada) (GEMIN et al., 2018). After scanning the aerial part of the plants, they were placed in paper bags and transferred to a forced air circulation oven at a temperature of $55^{\circ} \mathrm{C}$ until their weight stabilization, and then weighed on a precision scale to determination of shoot dry matter.

The variables length, surface area and root volume were also determined using the EPSON Expression 11000 Scanner equipped with additional light (TPU) with 600 dpi scanning. So that the roots were scanned, they were placed under a plastic plate containing a water slide, where they were separated so that the primary and secondary roots did not overlap during scanning, the results were analyzed with the aid of WinRhizo ${ }^{\circledR}$ software. After scanning, the roots were placed in paper bags and sent to a greenhouse at $55^{\circ} \mathrm{C}$ where they remained until the weight stabilization, followed by weighing to determine the dry matter of soybean roots.

After obtaining the data, they were submitted to variance analysis, and when significant, the means were compared by the $5 \%$ Scott-Knott test using the Sisvar software (FERREIRA, 2014).

\section{RESULT AND DISCUSSION}

A question that should be clarified prior to the use of Trichoderma based biological products is how doses of these products can act on plant development in a positive, negative or neutral manner, as well as whether there is interaction of these bioproducts when used with other biological bioproducts, often used in soybeans such as Bradyrhizobium japonicum.

Data obtained for soybean seedling emergence speed index in the treatment with the association Trichoderma sp. plus Bradyrhizobium japonicum liquid were lower than the other treatments (Table 2). The other treatments did not differ between themselves and the control. Similar data to those found in this study were observed when different combinations of bioproducts were used and even when using Trichoderma sp. associated or not with Bradyrhizobium. Ayoubi et al. (2012) report that 
there was no significant difference between treatments using Trichoderma spp. and Bradyrhizobium, alone or in association with the control treatment, for variable percentage of soybean seed germination.

Mattos (2017), describes that for variable speed index of emergence of soybean seedlings, in treatments using Trichoderma asperellum in isolation and associated with Azospirillum brasiliense or Bacillus spp., did not cause statistical differences when compared to treatment without inoculation.

Table 2 - Emergence of soybean seedlings at 10 days after sowing. Santa Maria-RS, 2018

\begin{tabular}{lc}
\hline Tratamentos & Emergência (\%) \\
\hline Control & $100,00 \mathrm{a}$ \\
T. harzianum & $100,00 \mathrm{a}$ \\
Trichoderma sp. & $100,00 \mathrm{a}$ \\
B. japonicum liquid & $100,00 \mathrm{a}$ \\
B. japonicum peat & $93,33 \mathrm{a}$ \\
T. harzianum + B. japonicum liquid & $93,33 \mathrm{a}$ \\
T. harzianum + B. japonicum peat & $100,00 \mathrm{a}$ \\
Trichoderma sp. + B. japonicum liquid & $80,00 \mathrm{~b}$ \\
Trichoderma sp. + B. japonicum peat & $93,33 \mathrm{a}$ \\
\hline CV\% & 6,93 \\
\hline
\end{tabular}

*Averages followed by the same letter do not differ statistically from each other by the Scott-Knott test at the $5 \%$ probability level.

It was observed for leaf variables (Table 3 ) that the treatments with the noncombined use of Trichoderma sp. and B. japonicum liquid presented higher means for all variables. When the combination of $T$. harzianum plus B. japonicum peat was used, there was an increase of $32 \%$ for the leaf area variable when compared to the control treatment. Regarding the shoot length data, the treatments Trichoderma sp., $B$. japonicum liquid and the association of $T$. harzianum plus B. japonicum peat and Trichoderma sp. more B. japonicum peat did not differ significantly from treatment without inoculation of bioproducts. For dry matter variable of aerial part, it was verified higher averages in the use of $T$. harzianum, Trichoderma sp. and B. japonicum liquid, which differed from the other treatments evaluated. 
Table 3 - Leaf area (A.F), shoot length (C.P.A), shoot fresh matter (M.F.P.A) and shoot dry matter (M.S.P.A) of soybean plants. Santa Maria-RS, 2018

\begin{tabular}{lcccc}
\hline Treatments & AF $\left.\mathbf{( c m}^{\mathbf{2}}\right)$ & CPA (cm) & MFPA (g) & MSPA (g) \\
\hline Control & $80,11 \mathrm{~b}$ & $15,27 \mathrm{a}$ & $2,28 \mathrm{~b}$ & $0,54 \mathrm{~b}$ \\
T. harzianum & $92,07 \mathrm{~b}$ & $13,40 \mathrm{~b}$ & $2,67 \mathrm{a}$ & $0,63 \mathrm{a}$ \\
Trichoderma sp. & $104,56 \mathrm{a}$ & $15,17 \mathrm{a}$ & $2,74 \mathrm{a}$ & $0,58 \mathrm{a}$ \\
B. japonicum liquid & $110,76 \mathrm{a}$ & $15,60 \mathrm{a}$ & $3,04 \mathrm{a}$ & $0,68 \mathrm{a}$ \\
B. japonicum peat & $74,04 \mathrm{~b}$ & $14,03 \mathrm{~b}$ & $2,09 \mathrm{~b}$ & $0,49 \mathrm{~b}$ \\
T. harzianum + B. japonicum liquid & $82,44 \mathrm{~b}$ & $13,83 \mathrm{~b}$ & $2,49 \mathrm{a}$ & $0,53 \mathrm{~b}$ \\
T. harzianum + B. japonicum peat & $105,82 \mathrm{a}$ & $15,77 \mathrm{a}$ & $2,69 \mathrm{a}$ & $0,53 \mathrm{~b}$ \\
Trichoderma sp. + B. japonicum liquid & $86,06 \mathrm{~b}$ & $13,30 \mathrm{~b}$ & $2,21 \mathrm{~b}$ & $0,45 \mathrm{~b}$ \\
Trichoderma sp. + B. japonicum peat & $83,05 \mathrm{~b}$ & $14,90 \mathrm{a}$ & $2,52 \mathrm{a}$ & $0,47 \mathrm{~b}$ \\
\hline CV \% & 8,56 & 6,23 & 8,82 & 8,40 \\
\hline
\end{tabular}

*Averages followed by the same letter do not differ statistically by the Scott-Knott test at $5 \%$ probability

When isolates of Trichoderma were using alone and associated with Bradyrhizobium japonicum in soybeans, AYOUBI et al. (2012) observed an increase of up to 2.5 times when compared to the control treatment for the variables shoot length, shoot and root fresh mass and root length. In the study by AZARMI et al. (2011), the authors used three trichoderma isolates (T. harzianum T969, T. harzianum T447 and the Trichoderma sp. Isolate) in two inoculation forms, where they observed that in soil modified by Trichoderma sp. and Trichoderma harzianum T969 increased leaf area of tomato seedlings. For variable seedling height (shoot length), the authors observed that isolates Trichoderma sp. and T. harzianum T969 presented height increase when compared to the control treatment.

According to Rufini et al. (2014), the Bradyrhizobium UFLA 03-320 and UFLA 03321 strains promoted plant growth, leading to increased plant height and shoot dry matter in dwarf guandu plants when compared to the other strains tested in experiment. Statistical superiority in the use of Bradyrhizobium sp. combined with Trichoderma harzianum for triticale culture in the shoot dry matter variable (GRANADOS et al., 2016).

The average root length in treatment Trichoderma sp. did not differ from the control treatment, and the other treatments presented comparatively lower means 
(Table 4), for the root surface area variable, Trichoderma sp. was superior to the other treatments.

Table 4 - Root length (C.R), root surface area (A.S.R), root volume (V.R) and root dry matter (M.S.R) of soybean plants. Santa Maria-RS, 2018

\begin{tabular}{lcccc}
\hline Treatments & C.R $\mathbf{( c m})$ & A.S.R $\left(\mathbf{c m}^{\mathbf{2}}\right)$ & V.R $\left(\mathbf{c m}^{\mathbf{3}}\right)$ & M.S.R $(\mathbf{g})$ \\
\hline Control & $1441,04 \mathrm{a}$ & $170,90 \mathrm{~b}$ & $1,61 \mathrm{a}$ & $0,151 \mathrm{~b}$ \\
T. harzianum & $1181,86 \mathrm{~b}$ & $171,82 \mathrm{~b}$ & $1,49 \mathrm{a}$ & $0,169 \mathrm{a}$ \\
Trichoderma sp. & $1728,33 \mathrm{a}$ & $226,64 \mathrm{a}$ & $1,73 \mathrm{a}$ & $0,179 \mathrm{a}$ \\
B. japonicum liquid & $1286,43 \mathrm{~b}$ & $146,32 \mathrm{~b}$ & $1,32 \mathrm{~b}$ & $0,173 \mathrm{a}$ \\
B. japonicum peat & $913,37 \mathrm{~b}$ & $135,32 \mathrm{~b}$ & $0,91 \mathrm{c}$ & $0,153 \mathrm{~b}$ \\
T. harzianum + B. japonicum liquid & $1010,32 \mathrm{~b}$ & $118,05 \mathrm{~b}$ & $1,10 \mathrm{c}$ & $0,143 \mathrm{~b}$ \\
T. harzianum + B. japonicum peat & $1091,88 \mathrm{~b}$ & $130,20 \mathrm{~b}$ & $1,23 \mathrm{~b}$ & $0,147 \mathrm{~b}$ \\
Trichoderma sp. + B. japonicum liquid & $1012,09 \mathrm{~b}$ & $133,27 \mathrm{~b}$ & $1,29 \mathrm{~b}$ & $0,144 \mathrm{~b}$ \\
Trichoderma sp. + B. japonicum peat & $1287,98 \mathrm{~b}$ & $155,22 \mathrm{~b}$ & $1,49 \mathrm{a}$ & $0,159 \mathrm{~b}$ \\
\hline CV \% & 14,83 & 17,00 & 12,29 & 8,55 \\
\hline
\end{tabular}

*Averages followed by the same letter do not differ statistically by the Scott-Knott test at $5 \%$ probability.

Regarding the root volume variable, treatment with Trichoderma sp. presented one of the highest means, but did not differ from the control treatment, T. harzianum and Trichoderma sp. more B. japonicum peat. The treatments T. harzianum, Trichoderma sp. and B. japonicum liquid showed an increase of 12\%, 18\% and 15\% in their results, respectively, when compared to the control treatment for the root dry matter variable (Table 4).

In the work of Juge et al. (2012), the authors observed that soybean root biomass was significantly increased when using Bradyrhizobium in combination with other bacteria (Azospirillum and arbuscular mycorrhizae) when compared to using Bradyrhizobium alone. According to Ayoubi et al. (2012), in soybean crop, an increase of 2 to 2.5 times the value of the control treatment was obtained for the variables fresh matter, dryness and root length, when compared with the treatments using Trichoderma harzianum and Bradyrhizobium sp. isolated and associated.

Azarmi et al. (2011) reported that the use of isolates Trichoderma sp. and T. harzianum T969 in soil, provided increase in root weight of both fresh and dried 
tomato seedlings. Egamberdieva et al. (2015) observed in their experiment that soybean inoculation with Bradyrhizobium japonicum BDYD1 resulted in increased root length and root dry weight, with root dry matter increasing up to $29 \%$. In the experiment conducted by Yedidia et al. (2001) using Trichoderma harzianum inoculated soil for cucumber cultivation, the authors report having observed a 100\% increase in root area and 75\% cucumber root length at 28 days after emergence in Trichoderma harzianum inoculated substrate.

At the work by Santos et al. (2014), for the study of the effect of nitrogen fertilization on symbiotic fixation with the Bradyrhizobium BR 3262 strain in cowpea it was possible to verify that the plants inoculated with Bradyrhizobium BR 3262, in the presence or not of nitrogen, had higher root mass, in relation to plants that were not inoculated.

It is noteworthy that treatment with Trichoderma sp. remained above or equal to the control, when compared to the other treatments studied in the variables mentioned in Table 4, showing the bioformulated action on the root development of soybean plants, the same results were found by Buso (2017), where there is a report. that inoculation with Trichoderma asperellum and Trichoderma virens alone resulted in greater root system development of soybean plants at 50 days after sowing.

\section{CONCLUSIONS}

The use of Trichoderma sp. and Bradyrhizobium japonicum liquid in their isolated form provide increase in plant leaf area, shoot length as well as fresh and dry shoot mass. In addition to the parameters related to root development, it was observed an increase in the length of roots and their dry mass. Thus, it is concluded that the use of Trichoderma sp. and Bradyrhizobium japonicum liquid alone provided better initial development for soybean crop. 


\section{REFERENCES}

AGUIAR, A.R.; AGUIAR, D.; TEDESCO, S.B. \& SILVA, A.C.F. Efeito de metabólitos produzidos por Trichoderma spp. sobre o índice mitótico em células das pontas de raízes de Allium cepa. Bioscience Journal. 2015;31(3): 934-940.

AYOUBI, N.; ZAFARI, D. \& MIRABOLFATHY, M. Combination of Trichoderma species and Bradyrhizobium japonicum in control of Phytophtora sojae and soybean growth. Journal Crop Protection. 2012;1(1):67-79.

AZARMI, R.; HAJIEGHRARI, B. \& GIGLOU, A. Effect of Trichoderma isolates on tomato seedling growth response and nutrient uptake. African Journal of Biotechnology. 2011;10(31): 5850-5855.

BÁBARO, I.M.; MACHADO, P.C.; BÁRBARO JUNIOR, L.S.; TICELLI, M.; MIGUEL, F.B. \& SILVA, J.A.A. Produtividade da soja em resposta à inoculação padrão e co-inoculação. Colloquium Agrariae. 2009;5(1): 01-07.

BENÍTEZ, T.; RINCÓN, A.M.; LIMÓN, M. C.; CODÓN, A. C. Biocontrol mechanisms of Trichoderma strains. International Microbiology. 2004;77: 249-260.

BRASIL. Ministério da Agricultura, Pecuária e Abastecimento. Regras para análise de sementes. Secretaria de Defesa Agropecuária - MAPA/ACS. 2009: 395-399.

BUSO, P.H.M. Contribuição de micro-organismos promotores do crescimento vegetal coinoculados na cultura da soja. Tese de Doutoramento. Curitiba, Universidade Federal do Paraná; 2017. 94 p.

CHAGAS, L.F.B.; CHAGAS JUNIOR, A.F.; SOARES, L.P. \& FIDELIS, R.R. Trichoderma na promoção de crescimento vegetal. Revista Agricultura Neotropical. 2017;4(3): 97-102.

CASSÁN, F.; PERRIG, D.; SGROY, V.; MASCIARELLI, O.; PENNA, C. \& LUNA, V. Azospirillum brasiliense Az39 and Bradyrhizobium japonicum E109, inoculated singly or in combination. Promote seed germination and early seedling growth in corn (Zea mays L.) and soybean Glycine max L.). European Journal of Soil Biology. 2009; 45(1): 28-35.

CONAB. Companhia Nacional de Abastecimento. Acompanhamento da Safra Brasileira: grãos. (Terceiro levantamento, p.1 - 127). Brasília, DF: CONAB. 2018.

DELABONA, P.S.; PIROTA, R.D.P.B.; CODIMA, C.A.; TREMACOLDI, C.R.; RODRIGUES, A.; FARINAS, C.S. Using Amazon Forest Fungi and Agricultural Residues as a Strategy to Produce Cellulolytic Enzymes. Biomass and Bioenergy 2012; 37:243-250.

EGAMBERDIEVA, D. \& JABBOROVA, D. Synergistic interactions between Bradyrhizobium japonicum and the endophyte Stenotrophomonas rhizophila and their effects on growth, and nodulation of soybean under salt stress. Plant Soil. 2016;45(1-2):35-45. 
ESPÍDOLA, C.J. \& CUNHA, R.C.C. A dinâmica geoeconômica recente da cadeia produtiva da soja no Brasil e no mundo. GeoTextos. 2015;11(1):217-238.

FRACETO, L.F.; MARUYAMA, C.R.; GUILER, M.; MISHRA, S.; KESWANI, C.; SINGH, H.B.; LIMA, R. Trichodema harzianum-base novel formulations: potential applications for management of Next-Generation agricultural challenges. Journal of Chemical Technology \& Biotechnology. 2018;93(8): 2056-2063.

FERREIRA, D.F. Sisvar: um guia para seus procedimentos de Bootstrap em múltiplas comparações. Ciência e Agrotecnologia. 2014;38(2):109-112.

GEMIN, L. G.; DATSCH, R.; MÓGOR, A. F. \& MÓGOR, G. Biofertilizer effect of yeast fermented broth on organic tomato seedlings. Revista de ciências agrárias. 2018;41(2):424-431.

GOKUL, B.; LEE, J.H.; SONG, K.B.; RHEE, S.K.; KIM, C.H.; PANDA, T. Characterization and applications of chitinases from Trichoderma harzianum - A review. Bioprocess Engineering. 2000;23(6):691-694.

GRANADOS, C.J.B.; PÉREZ, A.B.P.; CODOVI, U.A.; SANZ, M.Q.; RODRÍGUEZ, Y.G.; NÁPOLES, F.M. \& VALDÉS, A.M. Efecto de la inoculación com Bradyrhizobium sp. y Trichoderma harzianum em triticale (X. Triticosecale Wittmack), em condiciones de estrés por sequía. Pastos y Forrajes. 2016;39(1):19-26.

HUNGRIA, M.; MENDES, I.C. \& MERCANTE, F.M. (2013) - A fixação biológica do nitrogênio como tecnologia de baixa emissão de carbono para as culturas do feijoeiro e da soja. Embrapa Soja. https://www.embrapa.br/busca-de-publicacoes//publicacao/964424/a-fixacao-biologica-do-nitrogenio-como-tecnologia-de-baixaemissao-de-carbono-para-as-culturas-do-feijoeiro-e-da-soja. 10 Jun. 2018.

JUGE, C.; PRÉVOST, D.; BERTRAND, A.; BIPFUBUSA, M. \& CHALIGOUR, F.P. Growth and biochemical responses of soybean to double and triple microbial associations with Bradyrhizobium, Azospirillum and arbuscular mycorrhizae. Aplied Soil Ecology. 2012;61(1): 147-157.

KOZUSNY-ANDREANI, D.I. \& ANDREANI JUNIOR, R. Colonização rizosférica e promoção do crescimento por rizóbios em mudas de alface. Nucleus. 2014;11(2):443-452.

KUMARI, A.; KUMAR, R.; MAURYA, S.; PANDEY. P. K. Antagonistic potential of different isolates of Trichoderma against Rhizoctonia solani. European Journal of Experimental Biology. 2016;6(2): 1-6.

LEELAVATHI, M.S.; VANI, L.; REENA, P. Antimicrobial activity of Trichoderma harzianum against bacteria and fungi. International Journal of Current Microbiology and Applied Sciences. 2014;3(1): 96-103. 
MACHADO, D.F.M.; PARZIANELLO, F.R.; SILVA, A.C.F. \& ANTONIOLLI, Z.I. Trichoderma no Brasil: O fungo e o bioagente. Revista de Ciências Agrárias. 2012;35(1):274-288.

MATHIAS, V.; PEREIRA, T.; MANTOVANI, A.; ZÍLIO, M.; MIOTTO, P. \& COELHO, C.M.M. Implicações da época de colheita sobre a qualidade fisiológica de sementes de soja. Revista Agro@mbiente on-line. 2017;11(3):223-231.

MATTOS, M. Promoção de crescimento de soja a partir da inoculação de sementes com microrganismos não noduladores. Dissertação de Mestrado. Cerro Largo, Universidade Federal da Fronteira Sul; 2017. 47 p.

NETO, F.A.; PACHECO, L.P.; ARAÚJO, A.S.F.; PETTER, F.A.; ALMEIDA, F.A. \& ALBUQUERQUE, J.A. Tempo de contato e de combinações de fungicidas, aditivo e inoculante sobre a sobrevivência de rizóbios e nodulação da soja. Revista Agro@mbiente on-line.2014;8(1):149-154.

RUFINI, M.; OLIVEIRA, D.P.; TROCHMANN, A.; SOARES, B.L.; ANDRADE, M.J.B. \& MOREIRA, F.M.S. Estirpes de Bradyrhizobium em simbiose com guandu-anão em casa de vegetação e no campo. Revista Pesquisa Agropecuária Brasileira. 2014;49(3):197206.

SANTOS, K.C.; UCHÔA, S.C.P.; MELO, V.F.; ALVES, J.M.A.; ROCHA, P.R.R. \& XIMENES, C.K.S. Inoculação com Bradyrhizobium e adubação nitrogenada em feijão-caupi cultivado em diferentes solos. Revista AgroAmbiente On-line. 2014;8(3): 306-317.

SILVA, L.R.; PEREIRA, M.J;; AZEVEDO, J.; MULAS, R.; VELAZQUEZ, E.; GONZÁLES-ANDRÉS, F.; VALENTÃO, P.; ANDRADE, P.B. Inoculation with Bradyrhizobium japonicum enhances the organic and fatty acids contente of soybean (Glycine max (L.) Merril) seeds. Food Chemistry. 2013;141(14): 3636-3648, 2013.

VINALE, F.; FLEMATTI, G.; SIVASITHAMPARAM, K.; LORITO, M.; MARRA, R.;

SKELTON, B.W.; GHISALBERTI, E.L. Harzianic Acid, an Antifungal and Plant Growth Promoting Metabolite from Trichoderma harzianum. Journal of Natural Products. 2009;72(11): 2032-2035.

YEDIDIA, I.; SRIVASTVA, A.K.; KAPULNIK, Y. \& CHET, I. Effect of Trichoderma harzianum on microelement concentrations and increased growth of cucumber plants. Plant and Soil. 2001;235(2):235-242.

ZIMMER, S.; MESSMER, M.; HAASE, T.; PIEPHO, H.P.; MINDERMANN, A.; SCHILZ, H.; HABEKU, A.; ORDON, F.; WILBOIS, K.P.; HEB, J. Effects of soybean variety and Bradyrhizobium strains on yield, protein content and biological nitrogen fixation under cool growing conditions in Germany. European Journal of Agronomy. 2016;72: 38-46. 